INMR

19,3

180 Revised 9 October 2021
Received 21 June 2021 23 November 2021

Accepted 26 November 2021

\section{The innovative practices carried out in the collaborative complex of the city of Caruaru-PE}

\author{
Wilma Lucineide da Silva, Letícia Barbosa de Mélo and
}

Nelson da Cruz Monteiro Fernandes

Centro Acadêmico do Agreste, Universidade Federal de Pernambuco, Caruaru, Brazil

\begin{abstract}
Purpose - The study aims to analyze the innovative practices carried out in the collaborative complex in the city of Caruaru-PE.

Design/methodology/approach - The research is qualitative, carried out through a single-case study to analyze the innovative practices of Plural Colab. In data analysis, the authors have used the content analysis technique.

Findings - The results demonstrate the explanatory strength of the approach to innovative practices, highlighting people's daily engagement in the real work of innovation, which usually goes unnoticed in traditional approaches and models.

Originality/value - This study becomes essential given the need to research innovative management practices research. In addition, studies focused on innovation are generally directed to large companies, leaving aside the reality of micro and small business (MSBs) managers.
\end{abstract}

Keywords Innovation from a practical perspective, Innovative practices, Micro and small business

Paper type Case study

\section{Introduction}

Management activities related to innovation give rise to new knowledge and solutions on an ongoing basis, promote new organizational results and seek to advance, compete and differentiate successfully in the market (Cohendet \& Simon, 2017; Vasconcelos, Santos, \& Andrade, 2021). This attitude is vital because innovative organizations of any size achieve more significant economic growth than non-innovative ones. However, many small business innovation efforts still have little recognition, as traditional approaches to organizational management fail to encompass the actual day-to-day work of innovation, as Dougherty (2017) described. The approach to practices is a way to understand social phenomena in complex organizational contexts (Pimentel \& Nogueira, 2018), as is the case of micro and small business (MSBs) study that still has little recognition in the academic environment (Lima, 2018).

The practical perspective explains how the organization's people can routinely engage in innovation and work organized and systematically. In Dougherty's (2017) approach to innovation, subjects are not seen as cogs in a machine, but as professionals, who have their due importance within the company. Therefore, from a practical perspective, innovation involves variables and factors that no one can explain only through the changes in

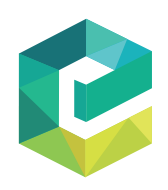

Innovation \& Management Review Vol. 19 No. 3,2022 pp. $180-191$ Emerald Publishing Limited $2515-8961$ DOI 10.1108/INMR-06-2021-0099
(C) Wilma Lucineide da Silva, Letícia Barbosa de Mélo and Nelson da Cruz Monteiro Fernandes. is published under the Creative Commons Attribution (CC BY 4.0) licence. Anyone may reproduce, distribute, translate and create derivative works of this article (for both commercial and non-commercial purposes), subject to full attribution to the original publication and authors. The full terms of this licence maybe seen at http://creativecommons.org/licences/by/4.0/legalcode.

The Foundation of Science and Technology of Pernambuco. Published in Innovation \& Management Review. Published by Emerald Publishing Limited This article 
organizational processes and structures. Furthermore, we must consider the organization as a process in which social relations occur (Janissek, Campos, Figueiredo, \& Melo, 2016).

Since Schumpeter's (1997) writings, the entrepreneur has played an essential role in the organization, thus, being seen as the central protagonist of the innovative process. We have placed the entrepreneurs as practitioners for this research due to their importance in developing innovations, specifically in MSBs. They are also responsible for their management and, the innovations are related to their characteristics (Najar \& Dhaouadi, 2020). Thus, the approach to practices can help understand their actions and sayings for carrying out innovative practices in their companies (Pimentel \& Nogueira, 2018; Schatzki, 2012).

However, studies involving innovative management practices are still under development in the Brazilian and foreign literature (Alves, Ferreira, Lins, \& Santos, 2021). In addition, Lima (2018) and Farah, Cavalcanti and Marcondes (2020), point out that studies focused on innovation are generally directed to large companies, which are the most innovative ones, causing researchers to end up leaving aside the reality of MSBs managers.

We have characterized this research as a single-case study to analyze the innovative practices carried out by a collaborative complex manager in the city of Caruaru-PE because the following reasons:

(1) Managers play crucial roles in creating, combining and recombining knowledge and resources to generate novelty.

(2) The lack of studies on innovation from a practical perspective turns into a considerable challenge for small businesses.

The chosen case justifies itself due to the form of management this complex's entrepreneur has adopted. He is the primary executor of innovation in the company. Therefore, he managed to create the first collaborative complex in the interior of Pernambuco, named Plural Colab. The complex is a micro-enterprise that started as a Collaborative Store, also something new in the region. Having that small local entrepreneurs do not count on enough funding, the Collaborative Store helps them have their physical Store or rent a niche in the space to display their products. However, the innovative actions of its manager allowed the expansion of the Store in such a way that it became a Collaborative Complex with two more businesses: Plural Café, a space where microentrepreneurs in the food industry can also exhibit and market their products; and Plural Coworking, an environment designed for self-employed professionals or students who need a professional place to study, hold meetings or even give lectures, courses or events.

The entrepreneur managed to make his business stand out among the MSBs in the region, through deliberate actions to meet particular demands not met in his locality, searching for the development of his innovative practices (Jornal Vanguarda de Caruaru, 2018). His protagonism and success made him socially recognized; he eventually became a topic for local newspapers; He started giving lectures at universities and entrepreneurial environments that also seek to develop innovation in the region.

Given the discussion presented, this research seeks to answer the following question: how does the manager of a collaborative complex in the city of Caruaru-PE carry out the practical work of innovation? To answer this question, we will use the three fundamental principles suggested by Dougherty, Dunne, Barnard and Elsbach (2005) to analyze the practical work of innovation in organizations.

\section{Theoretical reference}

\subsection{The entrepreneur's role for innovation}

According to Godin (2017), innovation started to be considered a central element for economic development as from the 19th century. Schumpeter (1939) has understood innovation as: (1) a
The innovative practices 
INMR

19,3

182 new product in the market; (2) a new, improved version of a product; (3) the execution of a new method in the production or sales process; (4) the opening of new markets; (5) obtaining new sources of raw materials or products; and (6) the installation of a new company structure.

Thus, Schumpeter highlights the entrepreneur role in the full accomplishment of innovation. This factor differentiates the entrepreneur from being just an inventor. He is an authentic agent capable of directing the idea from the initial invention to the commercialization phase through the combination of knowledge, skills, capabilities and resources that differentiate and add value (Cohendet \& Simon, 2017).

When we set out to study innovation, highlighting the entrepreneurs' person, our goal is to contribute to the studies of innovative practices carried out in small businesses (Alves et al., 2021), where the entrepreneurs are also responsible for management (Alhakimi \& Mahmoud, 2020; Lima, 2018). In this regard, our entrepreneur's definition adopts what Schumpeter (1997) proposed, who considers the entrepreneur the economic agent capable of putting innovation into practice in the market. His success will depend on his intuition when making decisions.

Innovation management happens through changes in the structure and involves new principles and relationships between people and work, aiming to overcome traditional management models (Alves et al., 2021). Experts generally establish such models on linear and closed approaches to innovation. The organizational principles are based on a functional structure, dividing the company into individual departments in which people are responsible only for specific activities (Cohendet \& Simon, 2017).

Thus, the adopting of new organizational principles through practices becomes essential to the new forms of work organization and the relationship between people in the organizational environment (Alves et al., 2021). In addition, the practical perspective provides " a clear and holistic understanding of the principles of the organization of innovation. These principles allow other inputs, such as intellectual capital, certain cultural norms and values, and visionary leadership to function effectively as facilitators of innovation" (Dougherty, 2017, p. 149).

\subsection{Innovation from a practical perspective}

According to Dougherty (2017) and Glückler and Bathelt (2017), practical perspective presents how innovation work happens in everyday reality. The practical perspective explains how the entrepreneurs carry out innovation in an interpersonal, contextualized way and through collective learning. "Using the practical perspective to understand the innovation work provides the basis for organizational capacity for continuous innovation and how to develop and maintain it" (Dougherty, 2017, p. 138).

For Pimentel and Nogueira (2018) and Sarquis, Pizzinatto, Sehnem, Pizzinatto and Duarte (2017), the literature dealing with the practical perspective can demonstrate how people are engaged in the real work of innovation. This approach contradicts the traditional management approaches, which consider workers as cogs in a machine, carrying out their activities in an individualized and technical way, each responsible only for their work. At the same time, the manager is responsible for supervising them. In the practical perspective conception, professionals master the ways of doing things, the stories, heterogeneous operations, knowledge and experiences necessary to solve real problems through viable solutions (Dougherty, 2017; Gouvêa, Cabana, \& Ishkawa, 2018).

Thus, a practical perspective should engage all professionals to make innovation feasible in the organizational environment, even those not directly linked to collective practices, but who understand their work as that of an innovator (Dougherty, 2017; Durante, Veloso, Machado, Cabral, \& Santos, 2019). For Pimentel and Nogueira (2018) professionals carry out the work methodically, and the teams, supported by collective learning, work in search of creating, combining and recombining knowledge to carry out innovations. 
In addition, it is worth mentioning Pimentel and Nogueira (2018) and Schatzki (2012), for whom practice, as a unit of analysis, allows us to understand the managers' performance based on the daily actions and arrangements that arise in the day-to-day routine of the organizational work. Practice allows the displacement of pre-established organizational structures, commands and strategies to know the organization based on its reality. In other words, it focuses on the practices of actions and not on pre-existing protocols and hierarchical decision-making.

Still, according to Dougherty (2017) and Schatzki (2012), this approach allows notoriety The innovative practices among agents and the agency, that is, the joining of human players and their performance in organizations. The work of a practitioner allows all the acquired knowledge and experience to be used strategically in times of challenges. Therefore, the developed knowledge and skills contribute to learn practically (Schon, 1983).

For Schon (1983), the reflective practitioner is the archetype of the knowledge society, the heart of practical activity, being able to act against the originally conceived plans and previously outlined tasks, either criticizing the elements of the organizational structure in which they are, or commanding to adapt to the emerging opportunities. Concurrently, the reflective practitioner acts as the subject who shapes the types of interpersonal relationships between peers to take advantage of the distributed knowledge and of each other's ideas to solve more complex issues. Based on Schon (1983), we can say that reflective managers have more to contribute to their own organization and to others since they have an adequate worldview, being a reflective subject.

According to Dougherty et al. (2005), people in innovative organizations generally embrace and adhere to the following three basic principles: (1) look for opportunities to add value and select the available alternatives; (2) take responsibility for the entire innovation process and expect everyone to contribute; and (3) seek and share knowledge.

McClelland (1961), pioneer of studies on entrepreneurial features, defines the first principle suggested by Dougherty et al. (2005) as the search for opportunities and initiative. According to the author, searching for opportunities and initiative leads entrepreneurs to get things done before being asked or pressured by external circumstances. To get things done quickly, entrepreneurs take advantage of the opportunities that appear to expand their business, act in new market areas, or even implement new products and services. Dornelas (2021) adds that attentive entrepreneurs can identify promising ideas before everyone else, but these promising ideas can also emerge from what other people cannot see. Thus, the entrepreneur holding this principle manages to transform promising ideas into something practical that generates value for the market, becoming a business opportunity.

Regarding the second principle of Dougherty et al. (2005), McClelland (1961) has already stated in his studies that the entrepreneur takes responsibility for the entire organizational performance. Entrepreneurs committed to the entire innovation process pursue objectives and goals, give support, put themselves in their employee's place and seek the satisfaction and loyalty of their customers, thus making the necessary efforts to accomplish the tasks.

The third principle discussed by Dougherty et al. (2005) dialogs with Dornelas (2021) when he states that entrepreneurs continuously seek knowledge, with the perspective of better knowing their field of activity. He adds that "this knowledge can come from practical experience, information obtained from specialized publications, courses or even advice from people who have set up similar undertakings" (Dornelas, 2021, p. 40). This perception corroborates the studies of McClelland (1961), who states that entrepreneurs seek to expand their knowledge field with the support of specialists, through advisory services (technical and commercial) and seek to obtain information about their market with the customers, suppliers and competitors.

However, Dougherty (2017, p. 139) points out that "knowledge based on practice is a collective entity, since no person can know all the heuristics or the principles involved, or have 
INMR

19,3

184

all the necessary experiences. Knowledge exists, therefore, in the practice of work" and, consequently, must be shared (Dougherty et al., 2005; Dougherty, 2017).

Still, according to Dougherty (2017), such principles are essential so that practicing managers can organize and control the organization by adopting the practices that best suit their business and competitive environment. The mentioned principles help managers create and implement their particular organizational principles (reflective action) to support innovation.

We assume that in MSBs, the focus of innovation is centered on the manager's personal characteristics (Najar \& Dhaouadi, 2020), in addition to the fact that entrepreneurs are also responsible for management (Alhakimi \& Mahmoud, 2020; Lima, 2018). Schumpeter (1997) considers the entrepreneur as an agent who performs innovation. Therefore, the studies by Dornelas (2021) and McClelland (1961), which deal with entrepreneurial features, can also explain the principles found in the study by Dougherty et al. (2005).

\section{Methodological procedures}

The present investigation approach is qualitative and the study is descriptive (Creswel, 2010). We have also characterized this research as a single-case study. The single-case strategy is well suited to contemporary phenomena that happen in reality, revealing itself as a typical single-case study because it seeks to study practices present in the daily life of the Plural Colab manager to carry out innovations (Yin, 2015).

We have considered this case relevant because the studied manager has characteristics of innovation and entrepreneurship that became a pioneer in creating the first Collaborative Complex in the Pernambuco countryside. Plural Colab is in the city of Caruaru-PE, inaugurated in May 2017 (Plural, 2020). Since then, it has become a reference in its segment, generating social impact, providing opportunities for local entrepreneurs to market their brands with less bureaucracy and at affordable prices. Plural Colab has contributed to the appreciation of local brands and movement of the region's economy and is a business with innovative sharing space.

We have chosen the manager of the collaborative complex Plural Colab as our research subject because he is the primary executor in his company's innovation process, as suggested by Lima (2018). He created his company from his undergraduate thesis, a learning process to overcome the challenges and avoid the risks on enterprises. Its innovative nature arose from knowledge accumulated overtime on the Administration and the endless search for information about the business. The manager created the company to contribute to the desires of his practical life, such as the search for financial independence and to generate a positive impact on society, especially by helping local microentrepreneurs (Santana, 2016). At the age of 24, he achieved social recognition in the "agreste" region (wild; which refers to the fields) by participating in lectures and events and interacting with his company's public in digital media.

For data collection, we have performed the triangulation according to the recommendations of Yin (2015), using two sources of evidence: a semi-structured interview and institutional documentation provided by the interviewed manager. In addition, as a second form of triangulation, the study authors validated the data (Creswel, 2010).

The interview script has seventeen questions, subdivided into three stages/categories that we have defined based on the principles of Dougherty et al. (2005). The first stage deals with the search for opportunities to add value, including the constructs of initiatives, business expansion, the emergence of ideas and taking advantage of opportunities. The second stage refers to taking responsibility for the entire innovation process and expecting everyone's contribution, covering the constructs of taking responsibility, supporting employees, contributing with everyone and satisfying customers. Finally, the third category is the search 
and sharing of knowledge, which comprises the constructs of market knowledge, expert support and knowledge sharing.

The interview happened online, with an average duration of one (1) hour, through the Google ${ }^{\circledR}$ Meet platform. With the manager's permission, we have recorded the statements to facilitate data collection transcribed in Word, totaling 16 (sixteen) pages to be analyzed. For data analysis, we have used content analysis as it corresponds to a set of communication analysis techniques that occurred in three phases. Pre-analysis, the first phase, is when we choose and prepare bibliographic documents referring to Plural Colab. Exploration, the second phase, consists of categorizing and constructing the constructs. We have defined the categories a priori based on the theory proposed by Dougherty et al. (2005) and based on its three basic principles. From this, we have incorporated in our script all themes involving each category, thus characterizing itself as a thematic categorization. The analysis, inference and interpretation of the data obtained from the interview and the documents used to support the research (Bardin, 1977) formed the third and last phase.

\section{Analysis of results}

\subsection{Search for value-adding opportunities}

It is possible to identify that the entrepreneur's initiative to open the business came from the practical experiences that emerged during his life. He has managed to act strategically and reflectively, as recommended by Dougherty (2017), McClelland (1961) and Schon (1983), presenting characteristics of alertness, intelligence, determination, curiosity and search for information (Dornelas, 2021). His actions corroborate the writings of Schumpeter (1997), who considers the entrepreneur as the principal-agent that performs innovation. Thus, entrepreneurs play a fundamental role in the implementation of innovation. Such entrepreneurs differentiate themselves from inventors, showing that they are the agents that transform their business ideas in their early stage and commercialize it through the combination of knowledge, skills, capabilities and resources, which differentiates and adds value.

During graduation, in fact [.. . ]I always had an enterprising spirit of wanting to open a business and such. [...] And then I came across the concept of Collaborative Economy there, on the inauguration of the creativity warehouse in 2015 [ . . . . However, the actual business model, collaborative store, I had contact with something very unrelated, watching a series on TV that is "adopted." [. . .]I kept that in mind and researched $[\ldots]$.

Then he said: "wow, this is the perfect business model to open my business!," Because it is different, like, it's disruptive, it socially impacts people and small entrepreneurs, right?! [. . .] And then I spoke to the teacher [...] and then he agreed to put the business plan in the undergraduate thesis.

The entrepreneur/manager of Plural Colab also seeks to expand his business, as suggested by McClelland (1961), starting to work in new areas of the market and implementing new services in his store. This way, since changing address right after the first year of operation, his company, has become a collaborative complex, sharing three different businesses in the new structure. Given this growth, he is already planning to franchise the company, thus corroborating the guidelines of Dougherty et al. (2005), Dougherty (2017) and Vaz-Curado and Mueller (2019). According to Dougherty et al., Vaz-Curado and Mueller, entrepreneurs allocate existing resources to the carry out new combinations besides selecting the alternatives and practices that best suit their reality and competitive environment.

In addition, despite the COVID-19 pandemic difficulties, he managed to expand Plural Colab by implementing an online sales channel, confirming the studies by Dougherty (2017), which state that the practitioner manages to strategically use the knowledge and experiences acquired in times of challenges and uncertainties. Following Dornelas (2021), the 
INMR

19,3

186

entrepreneur is also an identifier of opportunities and is visionary and curious. He has this characteristic of transforming such opportunities into something practical, generating value for the market. This willingness also endorses the studies of McClelland (1961), by stating that the entrepreneur can act even when external situations put pressure on him. He also knows how to adapt himself to the existing opportunities, as suggested by Schon (1983), since his venture was already a plan, but not a priority before the pandemic.

Regarding producing ideas for the changes implemented in Plural Colab, the interviewee states there is no systematic process. Ideas emerge from his practical experience, which happens in everyday life, through the exchange of knowledge with other people in addition to the knowledge acquired throughout his experiences, corroborating the studies of Dougherty (2017), Glückler and Bathelt (2017) and Schon (1983) on the reflective practitioner. According to the report, it is also possible to identify that his actions align with Dornelas' (2021) perspective which states that promising ideas arise from what other people cannot identify.

Regarding what is necessary to identify opportunities, we found that the interviewee seeks opportunities that generate value and that his practical learning contributes to this process. In addition, the manager states that to innovate, one must be brave enough to take risks with no guarantee of return, pointing out an entrepreneurial characteristic that McClelland (1961) addresses in his work. Such an entrepreneurial characteristic is not among the principles suggested by Dougherty et al. (2005), which more innovative organizations adopt.

Therefore, concerning the first principle of Dougherty et al. (2005), it is possible to observe that the manager is always attentive to opportunities and in search of expanding his business. Amid the period of social isolation caused by the pandemic of COVID-19, he expanded Plural through online platforms to reach his customers. The importance of his practical experience and determination to take risks also stands out to make it possible.

\subsection{Taking responsibility for the entire innovation process and expecting everyone to contribute}

Although he shares the management of Plural Colab with his partner, the entrepreneur is primarily responsible for managing the business and for innovative initiatives. This enormous responsibility makes evident that the entrepreneur/manager is the leading player in the process of recognition and action on opportunities, reinforcing the findings of authors such as Alhakimi and Mahmoud (2020), Alves et al. (2021) and Lima (2018), which results in innovation (Dougherty et al., 2005; Vaz-Curado \& Mueller, 2019). He seeks to take responsibility for achieving the company's goals and objectives, always committed to making work happen and overcoming obstacles, as Dornelas (2021) and McClelland (1961) suggested.

Plural Colab's manager is proud and accomplished with his company despite existing challenges. The manager has the characteristics addressed by Vaz-Curado and Mueller (2019) and these are fundamental characteristics, as they allow anticipating the effectiveness of innovative activities in the organization. Personal involvement, determination and energy to conduct innovations prove the importance of the entrepreneur's responsibility in this process (Dougherty et al., 2005; Dornelas, 2021; McClelland, 1961).

Another important issue suggested by McClelland (1961) and Dornelas (2021) is the manager supporting and putting himself in the place of the people involved in the organization (partner brands and employees). His business model requires everyone to be involved in the company's mission and vision, understanding his role as an innovator. The team must create, combine and recombine knowledge to make innovations. Thus, unlike traditional models, the manager not only inspects but involves everyone in the process of enabling innovation in the organizational environment, making them understand their work as that of an innovator (Durant et al., 2019; Pimentel \& Nogueira, 2018). 
Therefore, from a practical perspective, the management of innovation involves new principles of the relationship between people, considering the organization as a process in which social relations take place and where the practitioner is an essential player in implementing these realities. Thus, we have the analytical lens to identify the real work of innovation, explaining how the manager and the team perform it in an interpersonal, contextualized way and through collective learning (Alves et al., 2021; Dougherty, 2017; Glückler \& Bathelt, 2017).

Each partner brand is a unique initiative. Moreover, some people and dreams are equally unique [...]. practices

Our singulars are the raison d'être of Plural. There are dozens of brands and hundreds of people engaged, seeking to make a living from what they like to do, with purpose and making the creative economy in our region more prosperous and more plural [institutional archive]

Plural's manager shows that he cares about what employees are working on in his company. This care confirms what Dougherty (2017), Gouvêa et al. (2018) say. They state that employees are not cogs in a machine performing their functions individually and technically and that they are professionals who have their due importance in the organization. The manager puts himself in their shoes and wants them to grow. However, he admits he still needs to mature that aspect. The lack of conversations between managers and employees to clarify their personal and professional goals has prevented the alignment of expectations on both sides.

So, in agreement with Kracik (2017) and McClelland's (1961) idea, the entrepreneur is concerned with his partners' satisfaction. These partners own the brands and exhibit their products at Plural Colab who offers all the necessary support so that the collaborative store is a way for brands to achieve even greater goals. In other words, the entrepreneur assumes responsibility for Plural Colab's organizational performance, seeking to achieve the proposed goals, in addition to supporting its employees.

I got incredibly positive feedback that Plural has somehow made a difference for the brand, right!? For its presence, for its visibility. [... ]. They are satisfied, I think.

Furthermore, the manager is also concerned with growth, both for his partners and employees, corroborating Kracik's (2017) and McClelland's (1961), thoughts. They point out that the entrepreneur offers all the support for his collaborators and partners to evolve.

So, I want them to grow more, [ . . . ] and I think that most of them feel it [ . . ], it is not for nothing are there brands that have been with us since the beginning.

We played fair with him. We said that because of his time with us and his resourcefulness, we were highly interested in him taking up other positions within the company.

Dougherty (2017) state that, from a practical perspective, intellectual capital, some cultural norms, values and visionary leadership work as facilitators of innovation. Plural's entrepreneur understands that his training in administration, but mainly his skills, such as communication and creativity, are essential to direct the business and innovate in the face of market demands. It is a disruptive business model and requires different skills than the traditional ones. In addition, one can observe that the entrepreneur perceives himself as a fundamental person in the organization. He emphasizes the importance of his skills for the company, confirming the thought defended by Schon (1983) that the reflective practitioner has more to contribute to their company and others, given that, being a reflective subject, he has an adequate worldview.

It is also possible to observe that, as Dougherty et al. (2005) comment, in the most innovative organizations, the manager expects everyone to contribute to the innovation process. So does Plural's entrepreneur, incorporating activities and making efforts to apply 
INMR

19,3

188 all his knowledge and experience in specific situations and innovating in everyday practices and through the enterprise dynamics, which adopts innovation as an active process of actions. Therefore, it was necessary to build a document with all institutional information to align expectations of the store and the brands.

In relation to customers, according to Kracik's (2017) and McClelland's (1961) studies, the entrepreneur seeks his satisfaction by conducting the necessary actions for that. He has the necessary willingness to face the obstacles that permeate the innovation process and the challenges and complexities inherent to developing the solutions to add value to customers. We have observed that at Plural the manager seeks the satisfaction of his clients. Still, there is also a friendly relationship with people who believe in the business model, supporting local entrepreneurship.

Furthermore, regarding customer satisfaction addressed by McClelland (1961), Plural's entrepreneur understands that it is possible to effectively see this satisfaction when the customer enjoys the experience with the collaborative complex so much that they return to the store or recommend it to someone. Thus, as far as the second principle is concerned, we have found that the manager is responsible for the company's performance, aiming to achieve objectives and goals and seeking to align expectations with partners to develop innovation. However, it is also possible to notice that the entrepreneur made a mistake with the employee, as there was no conversation with him to address this alignment.

\subsection{Search and sharing of knowledge}

Plural's entrepreneur is always looking for knowledge to keep up with the business and the market, as suggested by Dougherty et al. (2005) and by Schon (1983). The authors mentioned above state that the reflective practitioner shapes interpersonal relationships to take advantage of the distributed knowledge and the peers' ideas to solve more complex situations. As the manager mentioned, during the social isolation caused by the pandemic of COVID-19, the business had its brick-and-mortar store closed, and he sought support and knowledge from other collaborative stores to face this difficult time. Thus, this also corroborates Dornelas (2021), when he states that the entrepreneur seeks knowledge on an ongoing basis, aiming at getting to know their industry better. This knowledge can come from both practical experiences and specialized publications, training or even pieces of advice from similar business entrepreneurs (Dornelas, 2021).

Like. .. researching, following people in the segment on social networks, consuming courses. [...] But participating in many events as well, [...] exchanging ideas with other entrepreneurs.

In addition, the manager has already had external support to assist in the company management, from both individuals and institutions such as the Brazilian Micro and Small Business Support Service (SEBRAE), the Federal University of Pernambuco (UFPE), Armazém da Criatividade and Rotary. Therefore, it is aligned with the thoughts of McClelland (1961) and Kracik (2017), who argue that the entrepreneur seeks to expand his knowledge field with the support of specialists, through advisory (technical and commercial) and obtains information about his market with customers, suppliers and competitors. However, in addition to this, Plural's entrepreneur, values the knowledge acquired through practice despite resorting to external support, corroborating the ideas of both Dougherty (2017) and Dornelas (2021) that knowledge exists in the practice of work.

Regarding the third principle of Dougherty et al. (2005) (which deals with knowledge), the Plural Colab's manager notices something interesting, when working until the wee hours of the night, or when working during the weekends: one of the main lessons learned from the company is the breaking of the romantic vision of the entrepreneur's work, which is widespread. Theoretical subjects at universities often disseminate this view, which is geared towards big business and exclude the experience of the small entrepreneur (Lima, 2018). 
Many students will face the reality of small business upon graduation. This reality corroborates Lima's (2018) criticism that there is little material on innovation aimed at MSBs. It confirms the need for this research aimed at MSBs and contributes to knowledge about this practices category of companies.

Therefore, it is a method of innovation necessarily centered on the manager/owner, who has a unique relationship with his company, unfolding as a worker, manager and entrepreneur to ensure the efficiency of innovation activities. In other words, the entrepreneur and his various roles are the main criteria for predicting the success of innovation, not the organizational structure when it comes to large companies (Silva, Dacorso, \& Montenegro, 2016).

Finally, it is possible to observe that the manager, in addition to seeking knowledge, also shares it with his partners, corroborating Dougherty et al. (2005) and Dougherty (2017), as both defend that knowledge exists through the practice of work and that it must be shared. This action of sharing demonstrates an instigating fact that the manager starts not only to look for external support to meet their needs but also to be external support for new entrepreneurs.

Thus, regarding the third principle, we have found that the entrepreneur shares the knowledge acquired through practical experience with partners, and he also shares the knowledge acquired through practical experience, as well as that acquired through external support. Therefore, an instigating factor emerges: the manager goes from one who seeks support to one who helps other entrepreneurs.

\section{Final considerations}

We have achieved this research target - analyze the innovative practices conducted by a manager of a collaborative complex in the city of Caruaru-PE - through the analysis of specific objectives, based on the three principles suggested by the model of Dougherty et al. (2005). Thus, it is possible to identify the importance of such an approach for understanding the innovative practices accomplished by this manager, who conducts the three principles studied and has the image of the reflective practitioner analyzed by Schon (1983), as he plays a fundamental role in his organization. In addition, it is possible to understand people's daily engagement in the real work of innovation, which usually goes unnoticed in traditional approaches and models.

As for the first principle, the manager is aware of opportunities and willing to expand his business. Just as happened during the restrictions period caused by the COVID-19 pandemic, he expanded the store to the online environment to reach his customers, making evident the importance of his practical experience and the courage to take risks. Regarding the second principle, it was possible to observe that the entrepreneur is responsible for the business performance, aiming to reach the objectives and goals and seeking to align expectations with his partners to develop innovation. However, the manager reported having failed with his employee as there was no conversation with him to address this alignment. As for the third principle, we have seen that the entrepreneur shares with his partners all the knowledge he acquired through practical experience and external support.

As a theoretical contribution to this study, there is an effort to approach innovation from a practical perspective, still under development, in the Brazilian and foreign literature (Alves et al., 2021). This effort happens because the practical perspective is focused on the category of MSBs, and studies that address innovation tend to focus on large companies, neglecting the experience of small entrepreneurs (Lima, 2018). As a practical contribution, the study can assist in the understanding and strengthening innovative practices carried out in small businesses and contribute for managers seek knowledge to make innovations in the literature focused on the realities they live. 
INMR 19,3

We have conducted the study with the manager of the collaborative complex addressed here. However, the study presented generalizable results, which could assist in the understanding of other realities and other similar undertakings. Therefore, we have suggested innovative studies in other companies to analyze innovation from a practical perspective in different contexts. When studying the managers' innovative practices, we have also suggested that future research consider the three principles of Dougherty et al. (2005) and the importance of the entrepreneur being brave enough to take risks, which is a point found in this research these authors did not raise.

\section{References}

Alhakimi, W., \& Mahmoud, M. (2020). The impact of market orientation on innovativeness: Evidence from Yemeni SMEs. Asia Pacific Journal of Innovation and Entrepreneurship, 14(1), 47-59. doi: 10.1108/APJIE-08-2019-0060.

Alves, B. N., Ferreira, A. A. L., Lins, E. R., \& Santos, E. C. (2021). Gestão da inovação como prática: Contribuições do conceito de gestão ordinária. Revista de Empreendedorismo e Gestão de Pequenas Empresas, 10(1), 1-11. doi: 10.14211/regepe.v10i1.1862.

Bardin, L. (1977). Análise de conteúdo. Lisboa: Edições 70.

Cohendet, P., \& Simon, L. (2017). Concepts and models of innovation. In Bathelt, H., Cohendet, P., Henn, S., \& Simon, L. (Eds.), The Elgar companion to innovation and knowledge creation (1st ed., Vol. 3, pp. 33-55). Cheltenham and Northampton, MA: Edward Elgar Publishing.

Creswell, J. W. (2010). Projeto de pesquisa: métodos qualitativo, quantitativo e misto (3rd ed.). Porto Alegre: Artmed.

Dornelas, J. C. A. (2021). Empreendedorismo: transformando ideias em negócios (8th ed.). São Paulo, SP: Empreende editora.

Dougherty, D. (2017). Innovation in the practice perspective. In Bathelt, H., Cohendet, P., Henn, S., \& Simon, L. (Eds.), The Elgar companion to innovation and knowledge creation (1st ed., Vol. 9, pp. 138-151). Cheltenham and Northampton, MA: Edward Elgar Publishing.

Dougherty, D., Dunne, D., Barnard, H., \& Elsbach, K. (2005). The rules and resources that generate the dynamic capability for sustained product innovation. In Elsbach, K. (Ed.), Qualitative organizational research (1st ed., Vol. 3, pp. 37-74). Greenwich: Information Age Publishing.

Durante, D. G., Veloso, F. R., Machado, D. Q., Cabral, A. C., \& Santos, S. M. (2019). Organizational learning in practice-based studies approach: Review of scientific production. Revista de Administração Mackenzie, 20(2), 1-28. doi: 10.1590/1678-6971/eRAMG190131.

Farah, O. E., Cavalcanti, M., \& Marcondes, L. P. (2020). Empreendedorismo estratégico: criação e gestão de pequenas empresas. São Paulo, SP: Cengage Learning.

Glückler, J., \& Bathelt, H. (2017). Institutional context and innovation. In Bathelt, H., Cohendet, P., Henn, S., \& Simon, L. (Eds.), The Elgar companion to innovation and knowledge creation (1st ed., Vol. 8, pp. 121-137). Cheltenham and Northampton, MA: Edward Elgar Publishing.

Godin, B. (2017). A conceptual history of innovation. In Bathelt, H., Cohendet, P., Henn, S., \& Simon, L. (Eds.), The Elgar companion to innovation and knowledge creation (1st ed., Vol. 2, pp. 25-32). Cheltenham and Northampton, MA: Edward Elgar Publishing.

Gouvêa, J. B., Cabana, R. P. L., \& Ishikawa, E. Y. (2018). As histórias e o cotidiano nas organizações: uma possibilidade de dar ouvidos àqueles que o discurso hegemônico cala. Revista Brasileira de Estudos Organizacionais, 5(12), 297-347. doi: 10.25113/farol.v5i12.3668.

Janissek, J., Campos, M. S., Figueiredo, Y. D. V., \& Melo, T. A. B. (2016). Avaliação da importância e adoção de inovações gerenciais na percepção de gestores de universidades públicas. Revista de Psicologia, 7(2), 49-66.

Jornal Vanguarda de Caruaru (2018). Comércio local dispõe da primeira loja colaborativa. Available at: http://jornalvanguarda.com.br/v2/?pagina=noticias\&id=24147 (accessed 1 October 2020). 
Kracik, M. S. (2017). Competências empreendedoras no âmbito social: um estudo dos participantes catarinenses do social good Brasil lab 2016. Dissertação. Universidade Federal de Santa Catarina.

Lima, G. S. (2018). Inovação na pequena empresa: desvendando conceitos, modelos e políticas de inovação. Ph.D tese. São Paulo, SP: Fundação Getúlio Vargas.

McClelland, D. C. (1961). The achieving society. New York, NY: VanNostrand.

Najar, T., \& Dhaouadi, K. (2020). Chief executive officer's traits and open innovation in small and medium enterprises: The mediating role of innovation climate. Journal of Small Business and Enterprise Development, 7(4), 607-631. doi: 10.1108/JSBED-04-2020-0109.

Pimentel, R., \& Nogueira, E. E. S. (2018). Estudos baseados na prática: possibilidades metodológicas para pesquisas em estudos organizacionais. Organizações e Sociedades, 25(86), 350-370. doi: 10. 1590/1984-9250861.

Plural (2020). Plural: feita de singulares. Available at: https://pluralcolab.com.br/ (accessed 15 September 2020).

Santana, M. O. F. (2016). Plano de negócios para uma loja colaborativa na cidade de Caruaru-PE: da teoria à prática. Caruaru: Trabalho de Conclusão de Curso, Universidade Federal de Pernambuco.

Sarquis, A. B., Pizzinatto, N. K., Sehnem, S., Pizzinatto, A. K., \& Duarte, A. C. (2017). Processo de inovação, fatores de influência e métricas de desempenho: proposta de modelo conceitual para empresa de base tecnológica. Revista de Administração da UNIMEP, 15(2), 73-99.

Schatzki, T. R. (2012). A primer on practices. In Higgs, J., Barnett, R., Billett, S., Hutchings, M., \& Trede, F. (Eds.), Practice-based education (6th ed., Vol. 12, pp. 13-26). Sense Publishers.

Schon, D. (1983). The reflective practitioner: How professionals think in action. New York, NY: Basic Books.

Schumpeter, J. A. (1939). Business cycles: A theoretical, historical and statistical analysis of the capitalist process (2nd ed.), New York: McGraw-Hill.

Schumpeter, J. A. (1997). Teoria do desenvolvimento econômico uma investigação sobre lucros, capital, crédito, juro e o ciclo econômico. São Paulo, SP: Nova Cultural Ltda.

Silva, G., Dacorso, A. L. R., \& Montenegro, L. M. (2016). Mais do que negócios abertos, mentes abertas. Revista de Empreendedorismo e Gestão de Pequenas Empresas, 5(2), 3-23. doi: 10.14211/regepe. v5i2.346.

Vasconcelos, R. B. B. D., Santos, J. F. D., \& Andrade, J. A. D. (2021). Inovação em micro e pequenas empresas: recursos e capacidades. Revista de Administração Contemporânea, 25(2), 1-19. doi: 10.1590/1982-7849rac2021190106.en.

Vaz-Curado, S. F. L., \& Mueller, A. (2019). The concept of entrepreneur of Schumpeter in comparison to Kirzner. Interdisciplinary Journal of Philosophy Law and Economics, 7(3), 1-31. doi: 10.30800/ mises.2019.v7.1223.

Yin, R. K. (2015). Estudo de caso: planejamento e método (5th ed.,). Porto Alegre: Bookman.

\section{Corresponding author}

Wilma Lucineide da Silva can be contacted at: wilma_ls@hotmail.com

For instructions on how to order reprints of this article, please visit our website:

www.emeraldgrouppublishing.com/licensing/reprints.htm

Or contact us for further details: permissions@emeraldinsight.com 